\title{
Susceptibility to Desertification in Chicualacuala, Republic of Mozambique
}

\author{
Inocêncio J. J. F. Pereira1, Flávio Rodrigues do Nascimento² \\ ${ }^{1}$ Faculty of Arts and Social Sciences, Eduardo Mondlane University, Maputo, Moçambique \\ ${ }^{2}$ Fluminense Federal University, Rio de Janeiro, Brazil \\ Email: inocêncio.pereira@gmail.com, flaviorn@yahoo.com.br
}

Received 11 January 2016; accepted 26 February 2016; published 29 February 2016

Copyright (C) 2016 by authors and Scientific Research Publishing Inc.

This work is licensed under the Creative Commons Attribution International License (CC BY). http://creativecommons.org/licenses/by/4.0/

c) (i) Open Access

\begin{abstract}
In this paper, a geo-environmental diagnostic was implemented to classify susceptibility to desertification in southern Mozambique (Chicualacuala) and deliver responses to revert occurring land degradation. The process of environmental diagnostic is a useful approach to identify the very processes and phenomena belonging to the wide ranging concept of land degradation.
\end{abstract}

\section{Keywords}

\section{Geo-Environmental Diagnostic, Susceptibility to Desertification, Mozambique/Chicualacuala}

\section{Introduction}

To date, although a great deal of data on land resources is available, it has not been possible to get a clear picture of the status of land degradation at regional or national levels [1]. The information needed is a basic and reliable estimate of the area affected by the degradation of natural resources in dry lands, using a well-accepted standardized methodological framework and principles that can be used by actors involved in combating desertification [1].

While concepts for desertification and land degradation have been conventionally established, "there is no consensus on the proper way to assess the desertification status of a piece of land" [2]. However, it is largely accepted that arid, semiarid and dry sub-humid areas, meaning "areas, other than polar and sub-polar regions, in which the ratio of annual precipitation to potential evapotranspiration falls within the range from 0.05 to 0.65 " are susceptible to desertification [3].

Desertification is assessed as land degradation. A general problem in desertification assessment is that land degradation is neither directly measured, because land degradation is derived from the broader environmental degradation concept, nor directly detectable and monitored [4]. It is indirectly measured through the very 
processes which represent natural environmental resource depletion [4]. Moreover, land degradation is a perceptual term, and thus, it is open to multiple interpretations "To a hunter or herder, the replacement of forest by savanna with a greater capacity to carry ruminants would not be considered degradation. Nor would forest replacement by agricultural land be seen as degradation by a colonizing farmer... Since degradation is a perceptual term, it must be expected that there will be a number of definitions in any situation." [5].

In that sense, the selection of criteria to call degradation to environmental changes is a specifically political choice, conditioned by the purpose of investigation and the categories of concern of the researcher [6]. An important question to consider is what processes and/or phenomena are indicative or proxies of land degradation [4].

According to Peprah [4] Symeonakis and Drake [7], in attempting an answer to this question, it is advised to recognise that there is a clear distinction between the indicators that are useful to have and those which are practical to obtain. Peprah [4] emphasized on how to choose the appropriate indicators and to combine their values so to obtain an overall result, interpreted as the value of a property, i.e., the measurand, for the system under analysis. Peprah [4] indicated that neither the case of biophysical indicators nor socio-economic indicators were conclusive. Hence, a synthesis is necessary but requires field test and verification to address the question concerning to whether land degradation has occurred.

Robbins [6] pointed out that the range of possibilities for criteria definition was endless, but some categories of importance to political ecologies included land degradation as 1) loss of natural productivity; 2) loss of biodiversity; 3) loss of usefulness; 4) creating or shifting risk ecology. Each of them is measured differently and each can be evaluated in multiple ways. The pitfalls in such measures are several however, and the degree to which ultimate and measurable "land degradation" free from political assumptions can be established is debatable" [6]. This shows that, when giving the status of land degradation at a particular geographic scale, specification of the category or categories of degradation taken into consideration in the concept and how, should be given.

Desertification should be sought in areas susceptible to desertification, noting that areas susceptible to desertification are not areas actually affected by desertification, and that "affected areas", in the context of UNCCD [8], are the "arid, semi-arid and/or dry sub-humid areas affected or threatened by desertification" (Article 1, point h). Figure 1 illustrates the difference between area susceptible to desertification and area affected by desertification.

Countries, whose lands include, in whole or in part, areas susceptible to desertification are encouraged to undertake research aiming at identifying areas currently affected by desertification and assessing the status of desertification of such areas. The demand for basic and reliable estimate of the area affected by degradation of natural resources poses challenges to science in respect to developing proper way to assess the status of land degradation or conservation.

\section{Objectives}

The aim of this paper is to show areas currently affected by degradation that were identified grounding on the diagnostic of susceptibility to desertification as research approach. It also presents potential responses to issues arising in the study area which is susceptible to desertification - the 18.065- $\mathrm{km}^{2}$-large region of Chicualacuala in Mozambique, at the southern triple-border of this country, South Africa and Zimbabwe (Figure 2).

Chicualacuala is an excerpt of tertiary-to-quaternary landscapes of southern Mozambique, subjected to dry desert (arid) and dry savanna (semi-arid) climate of the sub-tropical zone of southern Africa. It belongs entirely

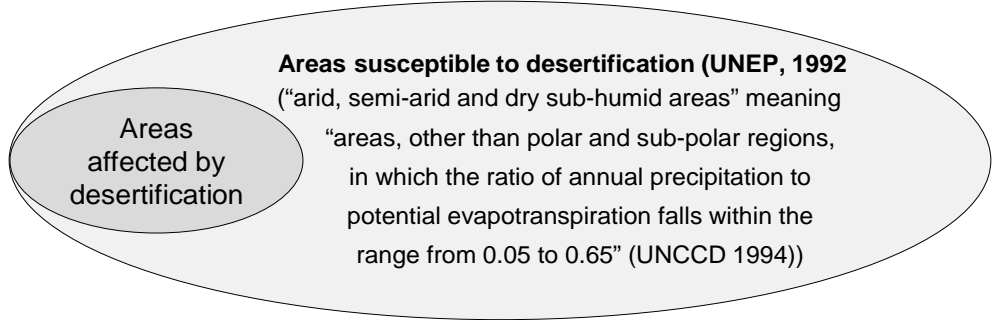

Figure 1. Relationships between susceptibility to desertification and desertification (source: prepared by the authors, based on Steiner and Sörensen [9]). 

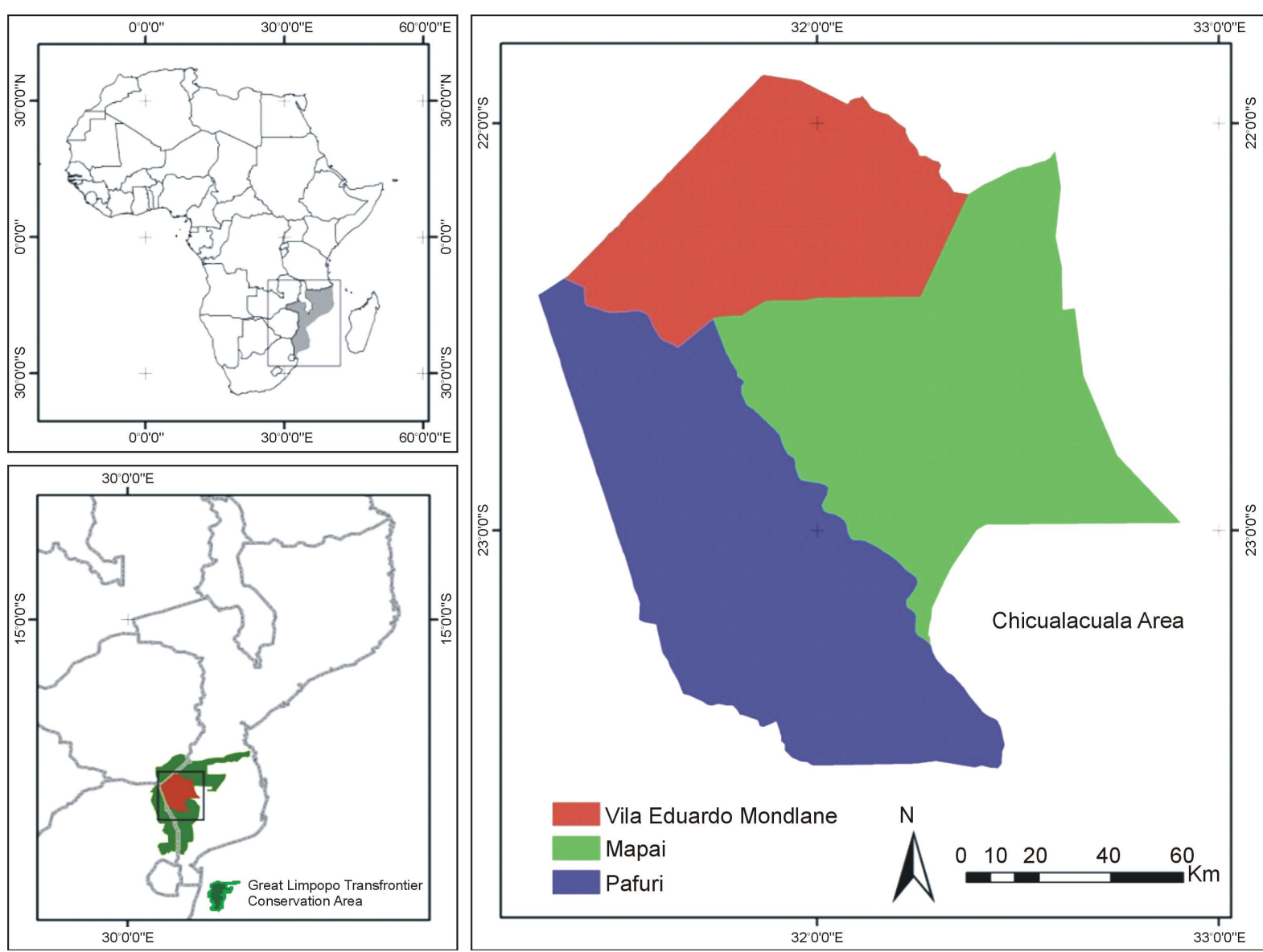

Figure 2. Chicualacuala: location in Southern Africa (Mozambique) and at the triple-border of Mozambique, South Africa and Zimbabwe (source: prepared by the authors).

to the projected Great Limpopo Transfrontier Conservation Area (TFCA) which includes the 2001-formally established Great Limpopo Transfrontier Park (TFP); covering a portion of the Limpopo National Park and of the Banhine National Park of Mozambique. The population was of 39.164 inhabitants in 2007, equivalent to a population density of 2.2 inhabitants $/ \mathrm{km}^{2}$ (III Census of the Population and Housing, 2007). Projection by the National Institute of Statistics in 2014 indicated Chicualacuala population ascending to 44.847 inhabitants in 2015 and to 49.135 inhabitants in 2020 [10].

Major kinds of land use in Chicualacuala comprise rain-fed, subsistence agriculture, extensive rearing of cattle, sheep and goats with the livestock fed in natural pastures; and exploitations of natural vegetation-for obtaining building materials, charcoal, extracts of herbal plants, etc. [11]-[15].

\section{Methodology}

We applied the geo-environmental diagnostic to achieve the above-stated objectives. Geo-environmental diagnostic is an integrative concept deriving from unified study of natural conditions that favours the perception of the milieu in which all life forms including man are to adapt [16]. Environmental diagnostic —or geo-environmental diagnostic which stresses commitments with geosciences-has been practiced as a framework for researching problems arising from man-environment interactions [16]-[21]. Land degradation, within or outside drylands, is such an environmental problem that is rooted in man-environment relationships.

By implementing geo-environmental diagnostic, the study area was compartmented first into topographic units on the basis of topography/altitude [22]; then, inventoried data and information relevant to land and landuse were integrated in these topographic units ensuing geo-environmental units.

A geo-environmental unit is defined as a spatialized entity in which the substrate (soil parent material), natu- 
ral vegetation, the landform and the nature and distribution of soils as a function of topography, constitute a set of problem-areas, whose variability is minimal, according to the cartographic mapping scale [17]. It consists biophysical aspects of the land and land use, standing out by offering opportunities to analyze vulnerabilities, risks and susceptibilities, and to assess potentials for sustainable development.

The so derived geo-environmental units express in a varied manner the very processes and phenomena that result from the ways land is occupied and managed (timing, operations and techniques for operation implementation). Such processes and phenomena reflect changes in the environmental structure and functions, some of which are precisely expressions of land degradation.

Since in the study area land use spreads across different geo-environmental units, in order to spatially demarcate areas of equal degree of susceptibility to desertification we used spatial distribution of villages and major kinds of land use/land utilization types. According to [23]-[25], a major kind of land use is a major subdivision of rural land use (e.g., rain-fed agriculture, irrigated agriculture, grassland, forestry, or recreation), while a land utilization type is a kind of land use described or defined in a degree of detail greater than that of a major kind of land use.

These two factors are related to key factors of land degradation as conceived by [8]: land uses or from a process or combination of processes, including processes arising from human activities and habitation patterns. The so demarcated classes of susceptibility to desertification have certain links with its origin and so, analysis of causes of land degradation and the search of potential responses to land degradation are carried out at the level of the identified categories.

\section{Results and Discussion}

\subsection{The Geo-Environmental Units}

In order to obtain geo-environmental units, we individualized "sets of landforms with similar characteristics" [22] in origin and topography/altitude, based on erosion cycles of the landscape evolution model by King [26]. Three topographic units can be recognized in Chicualacuala, at $>500 \mathrm{~m}, 200-500 \mathrm{~m}$ and $<200 \mathrm{~m}$ above sea level corresponding to the African, Zumbo and Congo (or Limpopo) erosion cycles, respectively.

They are correlated with the main land forms, namely great plateaus, middle plateaus and coastal plains, respectively; but also with aspects of the substrate (soil parental material) as well as of hydrology, natural vegetation, nature and distribution of soils and the distribution of major kinds of land use-all forming a system of relationships (geo-environmental units) in which only the land use is likely to occur across different units indicated its lower correlation with the compartments (Figure 3).

The matching of biophysical aspects of the land in Chicualcuala with land use as defined by type of land use and/or major kind of land use, land management practices, technologies employed and timing of land use operations, permits identifying processes and phenomena related to land degradation. Results of generalized field observations are summarized in Table 1. Land degradation was assessed analyzing processes and phenomena that combine and form "loss of usefulness of the land" [6] — a category for land degradation considered the commonest denominator for a wider range of other categories that build the concept of land degradation as defined by [8]. For instance, vegetation clearance aiming at obtaining land for farming and is being used for that aim is not considered degradation as the land then opened up is still useful and in use.

\subsection{Susceptibility to Desertification}

The susceptibility to desertification in Chicualacuala varies from through to high (Figure 4).

Descriptions of land degradation in the study area can be carried out using diagnostic factors. Diagnostic factors can be biophysical (land related), socioeconomic (related to socioeconomic aspects of land users, land use and technologies employed) as well as policy-related factors. They play different roles in understanding causal aspects of land degradation. For instance, policy related factors are useful to explain the magnitude and relevance of socioeconomic factors. The identification of diagnostic factors depends on the scale of analysis. At the lowest level, land use type or, more generally, the major kind of land use could be considered. At this scale of human activity it is possible to analyse relevant biophysical aspects of the land and their suitability for the current uses, type of land use, management practices and technologies employed to implement the various land use operations. Causes of land degradation can be evaluated, noting that they vary in nature as from natural factors through socioeconomic factors as well as policy/institutional factors. 
I. J. J. F. Pereira, F. R. do Nascimento

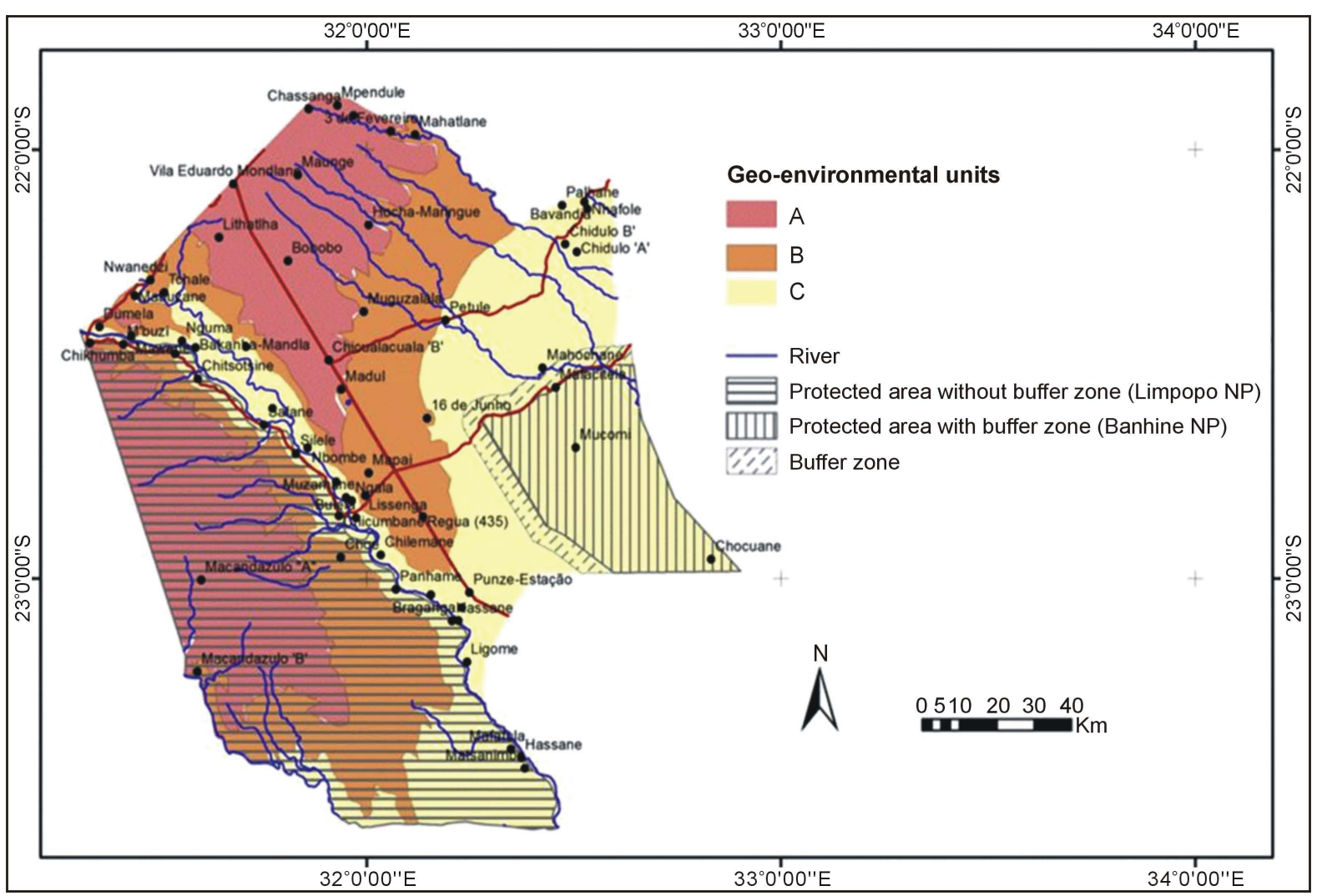

Figure 3. Geo-environmental units, Chicualacuala. Legend for A, B and C, see Table 1 on page 8). (Source: prepared by the authors).

Table 1. Problem-areas ensuing from man-environment interactions, Chicualacuala.

\begin{tabular}{|c|c|c|c|}
\hline \multicolumn{2}{|c|}{ Geo-environmental unit } & \multicolumn{2}{|c|}{ Processes \& phenomena and relevance } \\
\hline Biophysical characteristics & Dominant land use & Biophysical & Socioeconomics \\
\hline $\begin{array}{l}\text { A: Plateau; undulating; } \\
\text { well-drained sandier soils; } \\
\text { shallow tributary streams; } \\
\text { semi-deciduous vegetation }\end{array}$ & $\begin{array}{c}\text { Small-scale, extensive } \\
\text { dryland agriculture/livestock } \\
\text { and exploitations of } \\
\text { vegetation; partly } \\
\text { conservation }\end{array}$ & $\begin{array}{l}\text { Dryland ecosystem fragmentation } \\
\text { (moderate to high); Reduction of } \\
\text { vegetation density/diversity } \\
\text { (moderate); Increased soil dryness } \\
\text { (moderate to high); Soil nutrient } \\
\text { depletion in agroecosystems (moderate } \\
\text { to high); Erosion by wind (moderate) }\end{array}$ & $\begin{array}{l}\text { High intensity forest } \\
\text { exploitation; dryland farming on } \\
\text { small farm plots; Extensive } \\
\text { grazing on natural pastures; } \\
\text { Very low to low density of } \\
\text { population villages; partly } \\
\text { conservation }\end{array}$ \\
\hline $\begin{array}{l}\text { B: Gently sloping (long } \\
\text { slopes) partially steep slope } \\
\text { land; well- to moderately } \\
\text { drained sandy loam to loamy } \\
\text { sand soils, locally lithic; } \\
\text { deep tributary streams; } \\
\text { semi-deciduous vegetation }\end{array}$ & $\begin{array}{l}\text { Small-scale, extensive } \\
\text { dryland agriculture/livestock } \\
\text { and exploitations of } \\
\text { vegetation }\end{array}$ & $\begin{array}{l}\text { Dryland ecosystem fragmentation } \\
\text { (moderate); Reduced vegetation } \\
\text { density/diversity (high); Increased soil } \\
\text { nutrient depletion in agroecosystems } \\
\text { (moderate to high); Reduced thickness of } \\
\text { the uppermost soil horizon (moderate); } \\
\text { Erosion by water (moderate to high); } \\
\text { Increased dryness (moderate to high) }\end{array}$ & $\begin{array}{l}\text { Forest exploitation (low } \\
\text { intensity); dryland farming } \\
\text { on small farm plots; Extensive } \\
\text { grazing on natural pastures; } \\
\text { Low density of population } \\
\text { villages (sparse villages); } \\
\text { partly conservation }\end{array}$ \\
\hline $\begin{array}{c}\text { C: Plains and valley bottom } \\
\text { of the great river; clay-sand } \\
\text { sediments of surface runoff; } \\
\text { wetlands and lakes; } \\
\text { main rivers }\end{array}$ & $\begin{array}{l}\text { Small-scale, extensive, } \\
\text { manual-watered } \\
\text { agriculture/livestock; } \\
\text { partly conservation }\end{array}$ & $\begin{array}{l}\text { Siltation of lake and wetland } \\
\text { ecosystems (moderate); } \\
\text { Soil compaction (moderate); } \\
\text { Salinization (moderate); } \\
\text { Flooding (moderate) }\end{array}$ & $\begin{array}{l}\text { Forest exploitation (very low } \\
\text { intensity); dryland/wetland } \\
\text { farming on small farm plots; } \\
\text { Low partly very high density } \\
\text { of population villages; } \\
\text { partly conservation }\end{array}$ \\
\hline
\end{tabular}

Source: prepared by the authors. 
In the most part of the study area (60\%), the susceptibility to desertification is low. The area of low susceptibility is largely composed of the portions of the two national parks shared by Chicualacuala. The area of the Chicualacuala plains, with wetlands and a number of small lakes and swaps has also low susceptibility to desertification. The plateaus, consisting of well-drained sandier soils covered mainly by semi-deciduous vegetation with few shallow tributary streams, have high susceptibility to desertification (Figure 5).

Despite of relatively higher water availability in the plains and valley bottom of the great river, the susceptibility to desertification was considered moderate, given the high population density but truly the associated land use carried out based on the quality of land management practices in the area.

\subsection{On the Causes of Land Degradation}

It is not obvious that desertification is a "phenomenon induced by man" [27] and so it is irrational to expect people to knowingly behave in ways that destroy resources necessary for their survival or that of their future generations unless very strong pressures to do so are present [28]. The poor do not willfully degrade environment but poor families often lack the resources to avoid degrading their environment. The very poor, struggling

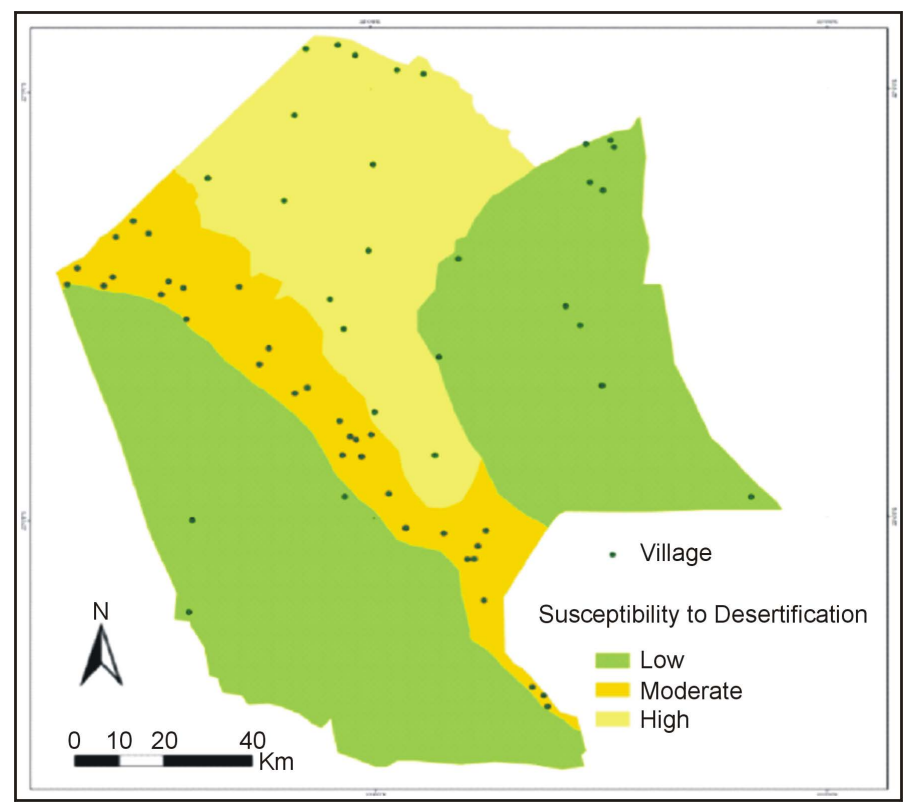

Figure 4. Generalised classification of susceptibility to desertification. (Source: prepared by the authors).

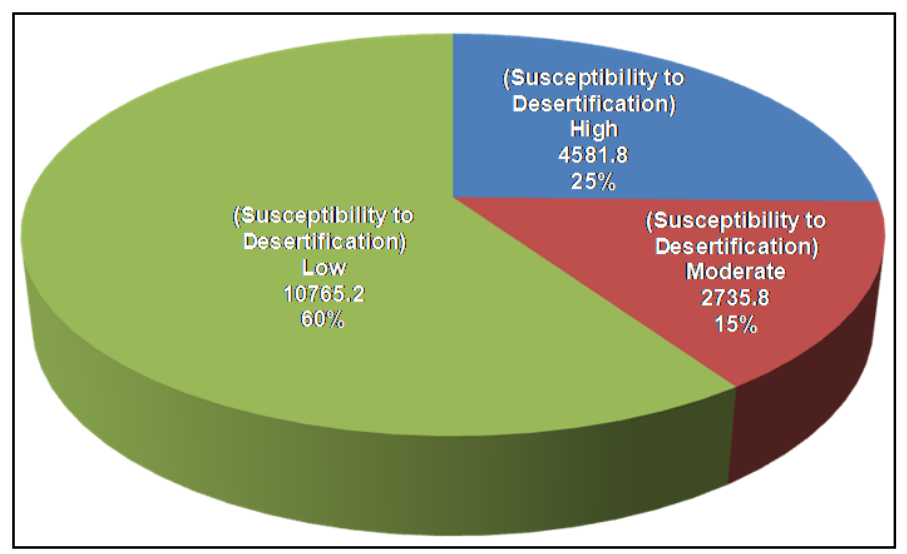

Figure 5. Susceptibility to desertification-statistics in square $\mathrm{km}$. (Source: prepared by the authors). 
at the edge of subsistence, are preoccupied with day to day survival. It is not that the poor have inherently short horizons; poor communities often have a strong ethic of stewardship in managing their traditional lands. But their fragile and limited resources, their often poorly defined property rights, and their limited access to credit and insurance markets prevent them from investing as much as they should in environmental protection. When they do make investments they need quick results [29]. It is obvious that local people recognize the insidious desertification taking place in their land, but they are more concerned about daily subsistence and cannot take action when the first signs of land degradation appear. One of the most tragic observations in dry ecosystems and probably everywhere among mankind is that with the increase of man-created bad environmental conditions, "inevitably each individual or each organization is trying to optimize utilization of particular components of the environment, all too often to the detriment of others" [28].

Four such pressures are discussed in the literature. These include 1) increases in population as mortality falls but fertility declines lag and 2) declines in common property resources. In addition there are international pressures; including 3) interest rate changes and 4) technology transfers [30]. Poverty generates significant incentives to have large families. Traditionally the impact of population growth on natural resources was discussed in terms of carrying capacity.

Conceptually, if nothing else changes, then, it is assumed that the increasing population will put demands on the resources that can no longer be met without damaging the ability of these resources to support human life. Social and economic factors such as trade, technology, consumption preferences and levels of inequality can alter the carrying capacity. Poor people will often use migration as a coping strategy. However, migration may not always benefit rural environments since the absolute numbers of rural people continues to increase [28].

Often the issues of poverty, population and the environment are interconnected and the whole correlates with environmental degradation [29]. "Greed for profit, on the one hand and poverty on the other, correlate positively with respect to environmental degradation, as both tend to look for quick results in their investments: some, targeting more and more wealth, and others, in need of quick results for their survival, all this occurring at the expense of conservation of natural resources" [29]. Pressures for the destruction of the resources needed for the survival of the local population or their future generations [30] may be alien; and regions of high levels of poverty have limited ability to unbridled and destructive exploitation of the biological potential of their land unless they are present additional factors for this. It is understood that the greed for profit (external pressure or local) and the need for survival (local pressure) supply ultimately a behaviour that can lead to harmful exploitation of biological potential. Policies and strategies are some of the known prevention mechanisms [30].

Much of vegetation exploitations occurring in Chicualacuala are carried out for supplying the Maputo market with firewood and charcoal for domestic use and for bread industry. Local communities intervene mostly as labour. In agriculture, the biggest problem is the depletion of soil nutrients, deformation of the soil physical structure (compaction) and soil erosion. Table 2 presents a profile of conservation legislation relevant to the study area that was set up in a period of approximately 25 years.

Table 2. Selected conservation legislations relevant to the study area, 1973-2001.

\begin{tabular}{cc}
\hline Game reserve/National park & Date \\
\hline $\begin{array}{c}\text { Banhine National Park, Mozambique } \\
\text { ("Coutada Oficial 17”) }\end{array}$ & Legislative Diploma No. 46/1973, June 26 \\
$\begin{array}{c}\text { Limpopo National Park, Mozambique (Conversion } \\
\text { of the former “Coutada Oficial 16”) }\end{array}$ & Decree No. 38/2001, November 27 \\
$\begin{array}{c}\text { Kruger National Park, South Africa (Conversion and increase } \\
\text { in area of the then Sabi Game Reserve established in 1898) } \\
\text { Gonarezhou National Park, Zimbabwe (Conversion } \\
\text { of the Game Reserve that existed as from 1934) }\end{array}$ & 1926, May 31 \\
$\begin{array}{c}\text { Great Limpopo Transfrontier Park, Mozambique, } \\
\text { South Africa and Zimbabwe }\end{array}$ & 2001 \\
Great Limpopo Transfrontier Conservation Area, \\
Mozambique, South Africa and Zimbabwe
\end{tabular}

Source: Stevenson-Hamilton (1974) and Legislation. 
People in Chicualacuala perceive land degradation (degradation of vegetation and of soil) in their own way: degradation of vegetation has several meanings ranging from scarcity of woody resources for building through to energy for cooking. For those from other parts coming into Chicualacuala for stalks, charcoal and firewood, degradation of vegetation means shortage of these products. Degradation of soil is felt as lowered yields in subsistence farming due mostly to depletion in soil nutrients aggravated by lower rainfall. It makes families shifting from one piece of cultivated land to another-which propagates the phenomenon across larger areas.

\subsection{Responding to Land Degradation}

The theory and practice of combating environmental degradation should be based on approaches that promote synergies between reduction of poverty, of loss of biotic diversity and promotion of best land management practices, while carrying out mitigation and adaptation to climate extreme events.

The modern global vision to combat environmental degradation is emanating from Agenda 21-one of the outcomes of UNCED (Rio 92). Measures to revert environmental degradation are based on the joint valuation and articulation the natural conditions (limitations and ASD's potential), the human factor (social and economic conditions) and institutional factor (Policy and strategies; science, local knowledge valuation; technology transfer) [8] [31].

On the other hand, the societal vulnerability to extreme events of the climate is imposing the need for introducing new variables in development planning, mandatory particularly in arid and semi-arid areas: reduce climate risk, mitigate climate drought and expand adaptation.

This constellation of approaches and measures (ranging from technocratic to those requiring change in human behavior) can be best structured and implemented within a context of a territorial environmental planning. Territorial environmental planning is the systematic assessment of land and water potential, and of alternatives for land use and economic and social conditions, in order to select and adopt the best land use options.

\section{Conclusions}

In arid, semiarid and dry sub-humid zones, man-environment relationships are subjected to conditions of stress; these zones are susceptible disruptions.

Within the realm of land degradation or conservation, they are thus termed areas susceptible to desertification meaning that desertification may rapidly reach levels at which the reversion of it becomes economically impracticable within actual geographic context of the area. They are suitable sites for researching desertification. Geo-environmental diagnostic is a useful approach to classification of susceptibility to desertification.

\section{References}

[1] UNCCD - United Nations Convention for Combating Desertification (2000) Assessment of the Status of Land Degradation in Arid, Semi-Arid and Dry Sub-Humid Areas. Dry-Land Degradation Assessment and the Millennium Ecosystem Assessment-Note by the Secretariat. Conference of the Parties (COP), 4th Session, Bonn, 11-22 December 2000, United Nations Convention to Combat Desertification, Bonn.

http://www.unccd.int/Lists/OfficialDocuments/cop4/inf6eng.pdf

[2] Verón, S.R., Paruelo, J.M. and Oesterheld, M. (2006) Assessing Desertification. Journal of Arid Environments, 66, 751-763. http://dx.doi.org/10.1016/j.jaridenv.2006.01.021

[3] UNEP-United Nations Environment Programme (1992) World Atlas of Desertification. London. 69.

[4] Peprah, K. (2015) Land Degradation Is Indicative: Proxies of Forest Land Degradation in Ghana. Journal of Degraded and Mining Lands Management, 3, 477-489.

[5] Blaikie, P. and Brookfield, H. (1987) Land and Degradation and Society. Methuen \& Co Inc., London, 284.

[6] Robbins, P. (2012) Political Ecology: A Critical Introduction. 2nd Edition, Blackwell Publishers, Oxford.

[7] Symeonakis, E. and Drake, N. (2010) 10-Daily Soil Erosion Modelling over Sub-Saharan Africa. Environmental Monitoring and Assessment, 161, 369-387. http://dx.doi.org/10.1007/s10661-009-0754-7

[8] UNCCD—United Nations Convention to Combat Desertification (1994) United Nations Convention to Combat Desertification in Countries Experiencing Serious Drought and/or Desertification, Particularly in Africa. Secretariat of the United Nations Convention to Combat Desertification. http://www.ecolex.org/server2.php/libcat/docs/TRE/Multilateral/En/TRE001200.pdf 
[9] Steiner, K. and Sörensen, L. (2011) Talking About. Annotated Glosssary on Combating Desertification and Sustainable Land Management. Deutsche Geselschaft für Internationale Zusammenarbeit (GIZ), Bonn.

[10] INE-Instituto Nacional de Estatística (2010) Projecções Anuais Da População Total, Urbana e Rural, Dos Distritos Da Província de Gaza. 2007-2040. Instituto Nacional de Estatística, Maputo. www.ine.gov.mz/

[11] INGC-Instituto Nacional de Gestão de Calamidades, UEM-Department of Geography and FEWS NET (2003) Atlas for Preparedness and Response to Disasters in the Limpopo Basin. Maputo.

[12] MAE-Ministério da Administração Estatal (2005) Perfil Do Distrito de Chicualacuala, Província de Gaza. Ministério da Administração Estatal, Maputo. www.govnet.gov.mz

[13] GPG-Governo da Província de Gaza (2006) Plano Estratégico de Desenvolvimento da Província de Gaza. Governo da Província de Gaza, Xai-Xai.

[14] Maposse, I.C., Ribeiro, N.S., Cambule, A.H., Sitoe, A.A. and Chiconela, T. (2010) Soils, Land Use and Suitability and Pasture Biomass in Chicualacuala. Report for the Joint Programme on Environmental Mainstreaming and Adaptation to Climate Change in Mozambique. United Nations Food and Agriculture Organization (FAO), Maputo. Faculdade de Agronomia e Engenharia Florestal, Universidade Eduardo Mondlane.

[15] Midgley, S., Dejene, A. and Mattick, A. (2012) Adaptation to Climate Change in Semi-Arid Environments-Experience and Lessons from Mozambique. Food and Agriculture Organization of the United Nations, Rome. http://www.fao.org/3/a-i2581e.pdf

[16] De Souza, M.J.N., de Freitas Rosa, M., de Figueiredo, M.C.B., do Nascimento, F.R., Araújo, L.D.F.P., de Oliveira Santos, J. and de Almeida Correia, L.J. (2005) Contexto Geoambiental das Bacias Hidrográficas dos Rios Acaraú, Curu e Baixo Jaguaribe-Estado do Ceará. Dezembro, Fortaleza, CE.

[17] Silva, F.B.R., Riché, G.R., Tonneau, J.P., Sousa Neto, N.C., Brito, L.T.L., Correia, R.C., Cavalcanti, A.C., Silva, F.H.B.B., Silva, A.B. and Araújo Filho, J.C. (1993) Zoneamento agroecológico do Nordeste: Diagnóstico do quadro natural e agrosocioeconômico. Embrapa-Cpatsa/Recife, Coordenadoria Regional Nordeste, Petrolina, 2v, v. 1, 11-43.

[18] Becker, B.K. and Egler, C.A.G. (1997) Detalhamento da metodologia para execução do zoneamento ecológicoeconômico pelos Estados da Amazônia Legal. MMA: Secretaria de Assuntos Estratégicos da Presidência da República, Brasília.

[19] Nascimento, F.R., da Cunha, S.B., de Souza, M.J. and da Cruz, M.L.B. (2008) Diagnosis Geoambiental of the River Acaraú River Basin Semi-Arid: Subsidies to the Studies on Desertification. Boletim Goiano de Geografia, 28, 41-62.

[20] Nascimento, F.R.D. (2009) Identificación de áreas vulnerables para el desetización en la cuenca intermitente estacional en el brasileño semiárido. Boletim Goiano de Geografia, 29, 71-82.

[21] Nascimento, F.R. (2013) O Fenômeno da Desertificação. Cegraf/UFG, Goiânia.

[22] Casseti, V. (2005) Geomorfologia. http://www.funape.org.br/geomorfologia/

[23] FAO_Food and Agriculture Organisation (1976) A Framework for Land Evaluation. FAO Soils Bulletin No. 32, FAO, Rome.

[24] Bai, Z.G., Dent, D.L., Olsson, L. and Schaepman, M. (2008) Global Assessment of Land Degradation and Improvement 1: Identification by Remote Sensing. Report 2008/01, FAO/ISRIC, Rome/Wageningen.

[25] FAO—Food and Agriculture Organisation (2007) Land Evaluation—Towards a Revised Framework. Land and Water Discussion Paper 6, Food and Agriculture Organisation (FAO), Rome.

[26] King, L.C. (1962) The Morphology of the Earth. A Study and Synthesis of World Scenery. Oliver and Boyd, Edinburgh.

[27] Mensching, H. (1990) Desertifikation: Ein Weltweites Problem der Ökologischen Verwüstung in Den Trockengebieten der Erde. Wissenschaftliche Buchgesellschaft, Darmstadt.

[28] Malik, S.J. (1998) Rural Poverty and Land Degradation: What Does the Available Literature Suggest for Priority Setting for the Consultative Group on International Agricultural Research? A Report Prepared for the Technical Advisory Committee of the Consultative Group on International Agricultural Research. http://ciat-library.ciat.cgiar.org/articulos ciat/2015/DINTER 0019.pdf

[29] World Bank (1992) World Development Report. Oxford University Press, New York.

[30] Lipton, M. (1997) Accelerated Resource Degradation by Agriculture in Developing Countries? The Role of Population Change and Responses to It. In: Vosti, S.A. and Reardon, T., Eds., Sustainability, Growth, and Poverty Alleviation, Johns Hopkins University Press, Baltimore.

[31] UNCCD-United Nations Convention to Combate Desertification (2007) The 10-Year Strategic Plan and Framework to Enhance the Implementation of the Convention (2008-2018). (Decision 3/COP.8 ICCD/COP(8)/16/Add.1). 